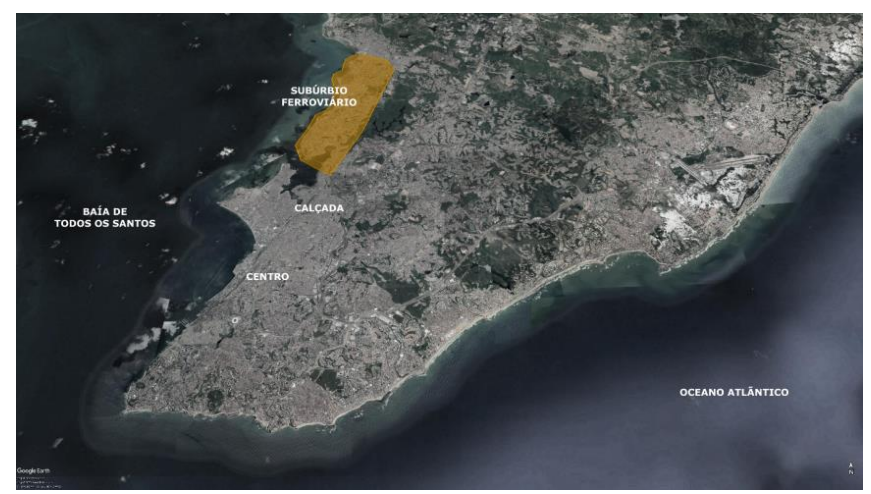

\title{
A utilização de registros sequenciais na avaliação do impacto na paisagem urbana do subúrbio ferroviário de Salvador
}

The use of serial vision in the visual impact evaluation on the urban landscape of the railway suburb of Salvador

Marcos Antonio Nunes Rodrigues ${ }^{1}$

ORCID: https://orcid.org/0000-0003-2363-8202

Márcia Maria Couto Mello

ORCID: https://orcid.org/0000-0002-2299-3117

Resumo: Este trabalho aborda a utilização da técnica de registro visual, sequencial, para realizar um estudo de modificação da paisagem urbana. Foi tomado como estudo de caso, o anteprojeto de implantação de uma linha de monotrilho na cidade de Salvador, numa região de orla marítima ao longo do seu subúrbio ferroviário. A técnica de registro sequencial foi desenvolvida pelos arquitetos ingleses Hugh Hastings e Gordon Cullen, ligados ao movimento Townscape e aqui é complementada por questões ligadas à legislação do patrimônio construído bem como pelas categorias de análise desenvolvidas pelos autores.

Palavras-chave: Paisagem urbana; Transporte público; Monotrilho; Cidade; Salvador.

Abstract: This work presents the use of the visual, sequential recording technique, in the realization of a study of modification of the urban landscape. The conceptual project for the implementation of a monorail line in the city of Salvador, in a coastal region along its railway suburb, was taken as a case study. The sequential registration technique was developed by the English architects Hugh Hastings and Gordon Cullen, linked to the Townscape movement and here it's complemented by questions related to the legislation of the built heritage as well as by the categories of analysis developed by the authors.

Keywords: Urban landscape; Public transport, Monorail, City, Salvador.

\footnotetext{
${ }^{1}$ Doutor pelo PPG/AU da UFBA, com estágio na Université Paris I (Sorbonne). Professor Associado I, da Faculdade de Arquitetura-UFBA. E-mail: marcosrodriguesarquiteto@gmail.com

${ }^{2}$ Doutora pelo PPG/AU da Universidade Federal da Bahia. Professora Titular do Programa de PósGraduação em Desenvolvimento Regional e Urbano da Universidade Salvador / UNIFACS. E-mail: mellomarcia@uol.com.br
} 


\section{Introdução}

Ao longo de todo o século XX, diversos campos do conhecimento se apropriaram do conceito de paisagem urbana para dar conta de abordagens e objetos diferentes. Notadamente podem ser citados os geógrafos, os arquitetos paisagistas e os urbanistas. A este grupo se juntaram, mais recentemente, os turismólogos, os patrimonialistas e os sociólogos.

A expressão "paisagem urbana" aparece na Inglaterra e na França, no final do século XIX, dentro do campo da literatura e da crítica de arte. De forma mais operativa, a expressão "townscape" aparece na Inglaterra como um campo a ser investigado na década de 40, do século passado, por nomes ligados à revista The Architectural Review, como Hugh de Cronin Hastings e Gordon Cullen. Esses autores colocam o foco da análise da paisagem urbana na dimensão visual, argumentando a possibilidade de uma investigação objetiva, física, se afastando das interpretações subjetivas, de análise de conteúdo, como as que marcaram a tradição alemã e norteamericana em torno do conceito de "paisagem cultural" (RODRIGUES, 2009).

O presente estudo parte dessa linha inglesa de ideias defendidas por Hastings e Cullen, na década 1960, e propõe a possibilidade de um estudo de impacto visual na paisagem urbana, considerando premissas objetivas da apreensão visual a partir de registros sequenciais feitos a partir de fotografias.

Como estudo de caso foi escolhido o projeto em curso da implantação de uma linha de monotrilho em estrutura elevada, em Salvador, num trecho que vai da Estação da Calçada ao bairro de Paripe, seguindo o percurso da atual linha férrea que corta o Subúrbio Ferroviário da cidade. A escolha do objeto deu-se pela crescente discussão e polêmicas em torno da implantação de modais de transporte em estruturas elevadas na cidade, bem como pela disponibilidade de dados e informações sobre o projeto em curso.

A estrutura a ser implantada para funcionamento do monotrilho se estende, no trecho citado, por cerca de $13,5 \mathrm{~km}$, com a quase totalidade do percurso em estrutura de concreto (pilares e vigas) que eleva o trilho a alturas variáveis do solo.

As análises foram feitas com bases nas informações de anteprojeto fornecidas pela concessionária do serviço a ser implantado, confrontando com levantamentos de dados feitos in loco e da legislação existente. Dessa forma, a investigação contempla as questões ligadas à visibilidade, na acepção direta do termo - o que os olhos podem captar num golpe de vista - e as confronta com as questões ligadas às restrições legais de proteção 
paisagística e do patrimônio construído, bem como à percepção coletiva das paisagens desse trecho e que abarcam aspectos da identidade dos lugares e imagem da cidade.

O trabalho se estrutura com uma breve caracterização do Subúrbio Ferroviário, do ponto de vista da constituição da sua paisagem construída. Numa parte teórica são definidos os conceitos de Paisagem Urbana e Imagem da Cidade utilizados nesse estudo, tomando como base autores clássicos e estudos recentes e, por fim, um estudo de caso do impacto na paisagem da implantação do monotrilho em Salvador.

\section{O subúrbio ferroviário de Salvador}

O percurso que a primeira etapa do monotrilho vai percorrer, indo da Calçada ao bairro de Paripe, seguindo no mesmo leito da antiga rede ferroviária, passa por inúmeros bairros do chamado Subúrbio Ferroviário de Salvador, como Lobato, São João do Cabrito, Plataforma, Itacaranha, Praia Grande, Periperi, Coutos e, finalmente, Paripe. Uma região onde vivem mais de 200 mil pessoas, cerca de $11 \%$ da população da cidade (IBGE).

O trecho, que já foi ocupado por aldeias indígenas, atravessou o período colonial basicamente como área de engenhos e tem na Capela de Nossa Senhora da Escada, em Itacaranha, um dos últimos registros dessa época. Mas o Subúrbio Ferroviário tem a sua história mais fortemente ligada à implantação da linha férrea, em junho de 1860, pela empresa inglesa Bahia and San Francisco Railway Company, interligando Salvador à cidade de Alagoinhas, bem como ao consequente período industrial da cidade, com as primeiras ocupações se dando, também, no final do Século XIX, no bairro de Plataforma (VASCONCELOS, 2016).

Foram as fábricas de tecidos, calçados e sabão de Antonio F. Brandão, bem como a Fábrica São Braz (1891), de tecidos, da família Martins Catharino, que ainda tem as suas ruínas como parte constituinte da paisagem do bairro, que induziram a ocupação inicial da área. Registra-se ainda em 1837, a inauguração de uma olaria na região de Escada. As fábricas e as estruturas da linha férrea constituíram ao longo de quase todo o Século XX, a paisagem construída característica da região e fazem parte da constituição da sua imagem. O nome Subúrbio Ferroviário dá bem o tom dessa importância.

Os outros elementos que, historicamente, definem a paisagem e a imagem do Subúrbio Ferroviário são a costa marítima da Baía de Todos os Santos - por onde a linha férrea define o seu percurso, a margeando - e a falha geológica de Salvador, que divide a 
cidade em Alta e Baixa, estabelece suas encostas e é elemento fundador e definidor da cidade, se estendendo também por essa região, criando uma espécie de plano de fundo.

A primeira metade do Século XX passou sem grandes alterações nessa paisagem até que, a partir da década de 1950, grandes loteamentos populares como Jardim Lobato, Jardim Itacaranha, Jardim Meirelles (Paripe), Jardim Praia Grande e Coutos começassem a ser implantados na região. É nos interstícios de áreas livres desses empreendimentos que também começam a se instalar as invasões que avançam entre décadas de 1960 e 1980, contribuindo com o adensamento atual e uma paisagem marcada pela autoconstrução (VASCONCELOS, 2016).

A instalação do Centro Industrial de Aratu, em 1967, atraiu uma massa migratória, sobretudo para o bairro de Paripe e a abertura da Avenida Afrânio Peixoto, também conhecida como Avenida Suburbana, com seus 14km, em 1971, estabeleceu uma nova via de importância para essa área da cidade e impulsionou a ocupação e o adensamento que marca a paisagem atual, com ocupações irregulares em suas encostas.

Pode-se dizer, assim, que o chamado Subúrbio Ferroviário tem, então, dois momentos distintos que marcam mais fortemente a constituição das suas paisagens e da sua imagem. Um primeiro que começa no final do Século XIX e se estende até os anos de 1970, com a implantação da linha férrea e instalação de equipamentos industriais e, um segundo momento com a chegada dos grandes loteamentos populares - seguidos por invasões de terras - que tem seus processos acelerados pela nova avenida que estabelece uma lógica rodoviária.

No primeiro momento tem-se a predominância de uma paisagem voltada para a Baía de Todos os Santos. Seja pela linha do trem ou pela implantação dos equipamentos industriais onde, pela grande escala, alguns marcos visuais se destacam: a ponte São João, a Fábrica São Braz e a Companhia de Cimento Salvador (COCISA). Desse período também ficam marcados os trechos balneários de praias tranquilas, bem como as comunidades de pescadores. E, um segundo momento, onde se somam a essa paisagem do período Moderno, a grande massa amorfa e genérica (KOOLHAAS, 1995) das autoconstruções que ocupam tanto a borda marítima quanto as encostas da falha geológica da cidade, cortadas pela Avenida Afrânio Peixoto. 


\section{Paisagem urbana e imagem da cidade}

As cidades são o lócus privilegiado da circulação. Dos corpos, dos objetos, das informações. Tem sido assim desde os primórdios dos assentamentos humanos. Um aspecto fundamental, então, para o entendimento das paisagens urbanas contemporâneas, como as que são encontradas no Subúrbio Ferroviário de Salvador, são as questões ligadas à circulação e à velocidade. Até o fim do século XVIII - uma época relativamente recente, perto da história da humanidade - pode-se considerar que os deslocamentos e a circulação de informações eram feitos num movimento lento. Sobre a parte terrestre do planeta esses movimentos eram baseados na força muscular de homens e animais. No mar, eram baseados na utilização do vento. As velocidades variavam da imobilidade ao deslocamento por cavalo a galope $(13 \mathrm{~m} / \mathrm{s})$, com as velocidades médias em torno de $3 \mathrm{~m} / \mathrm{s}$. O que permitia o deslocamento máximo de $200 \mathrm{~km} / \mathrm{dia}$, o mesmo ao equivalente no mar. Esse desempenho era, no entanto, excepcional. O mais comum é que viajantes fizessem seus percursos a uma velocidade de 35 a $40 \mathrm{~km} /$ dia, o que significa uma média de 6 a 7 km/hora (VIRILIO, 1993).

Nas grandes cidades europeias, a primeira metade do século XIX é marcada pelos bondes com tração a cavalo. Transportando uma dezena de pessoas esses veículos atingiam uma velocidade de 8 a $9 \mathrm{~km} / \mathrm{h}$. A velocidade humana só conheceu outro patamar com a invenção do telégrafo ótico de Claude Chappe, em 1794 e, sobretudo a partir da segunda metade do século XIX com o desenvolvimento da máquina a vapor e o seu uso em locomotivas e navios. Em1879 aparecem os primeiros bondes elétricos em Berlim e logo depois os trens metropolitanos e transformam de vez a paisagem das cidades (Paris em 1900, Berlim em 1902, Nova Iorque em 1904 e Londres em 1905) . A cidade passa a ser entendida como de duas naturezas: àquela herdeira da idade média, de percursos pedestres (walking city) e a cidade ferroviária, descrita como um polvo (octopus). Uma terceira forma de cidade, difusa, foi engendrada a partir do aparecimento do automóvel. O Subúrbio Ferroviário de Salvador é uma síntese desses três processos.

A aceleração da velocidade dos transportes ampliou os deslocamentos humanos. Até o começo do período moderno os habitantes das cidades não representavam mais do que uma porcentagem muita limitada da população do mundo. O fenômeno urbano era basicamente constituído de pequenas cidades com menos de 20 mil habitantes, estabelecidos num território pouco hierarquizado. Com o aumento da mobilidade e dos conseqüentes processos migratórios, no entanto, uma cidade central como Paris já 
possuía, em 1851, um milhão de habitantes. No mesmo ano, Londres registrava 2,5 milhões de habitantes. Em 1881 as cidades já contavam com 1,9 milhões e 3,9 milhões, respectivamente. Foi a estrada de ferro, ou sua ausência, que permitiu, ou não, o crescimento das cidades (RODRIGUES, 2009).

A velocidade ampliou também os territórios. Entre 1800 e 1999 a população de Paris se multiplicou por vinte, enquanto que a superfície ocupada pela cidade se multiplicou por sessenta e cinco. Em Salvador, no início da década de 1970, a abertura da Avenida Paralela, na direção norte da cidade, cria as condições para que dois terços das terras do município, até então intocadas, possam ser incorporadas à lógica de mercado e permitam uma expansão da cidade sem precedentes. A imagem da cidade se dilui entre a paisagem do velho centro colonial e as novas paisagens da arquitetura moderna tardia nos espaços desenhados para a mobilidade motorizada. O papel do automóvel passa a ser decisivo no espraiamento de Salvador em direção às periferias.

No espaço de um século as velocidades das redes de infraestrutura se multiplicaram por dez e as distâncias foram "divididas" por dez em termos de tempodistância. A distância de Paris a Strasbourg, cerca de 500 km, é feita hoje pelo TGV (train à grande vitesse) no tempo de $2 \mathrm{~h}$. E, com as telecomunicações, a circulação de informações se faz hoje na velocidade da luz. A explosão dos modos e das velocidades de deslocamento não eliminou a lentidão, no entanto. $O$ padrão atual da circulação humana é basicamente heterogêneo, onde grandes velocidades coexistem com os andamentos pré-modernos. Seja nas escalas horizontais, das distâncias planas pelo globo terrestre; seja nas escalas verticais, das possibilidades diferenciadas de consumo.

Esta sucessão de modos de transporte conduziu às formas híbridas da cidade. As diversas velocidades em coexistência são hoje fatores decisivos para entender a organização dos espaços urbanos e as transformações de suas paisagens. Os deslocamentos em grande velocidade (TGV, aviões), por exemplo, estão em oposição direta à quantidade de paradas: não se pode "descer" em qualquer lugar. Faz parte do desenvolvimento das infraestruturas de transporte que a aceleração das velocidades esteja ligada a um alongamento dos percursos e de uma redução do número de nós, traduzidos em portos, aeroportos e estações de transbordo diversas. As redes técnicas de transporte e informação estenderam os limites dos territórios, alteraram as tramas urbanas e criaram uma espacialização diferenciada, selecionando os pontos de conexão e os lugares de 
A utilização de registros sequenciais na avaliação do impacto na paisagem urbana do subúrbio ferroviário de salvador

passagem. Do ponto de vista econômico, a estruturação dessas redes; processo necessariamente seletivo, valoriza e potencializa alguns lugares em detrimento de outros.

De certa forma, o início da velocidade na circulação de pessoas, informações e objetos, já coincide com a ampliação da concorrência e da seleção entre os lugares. Já foi visto que a velocidade fabrica territórios heterogêneos e desiguais. Fabrica, até mesmo, uma certa invisibilidade dos lugares intersticiais. Essa "invisibilidade" se repete em muitos pontos do Subúrbio Ferroviário e acaba por definir as regiões que são identificadas nesse estudo. A vastidão dos territórios fica "apagada", como se só existissem pontos de partida e chegada. Virilio (1984) observa que o Concorde, com sua travessia entre Paris em Nova Iorque realizada no intervalo de duas horas e meia, "apagava”, de certa forma, o Oceano Atlântico.

Os efeitos da grande velocidade nos lugares de passagem podem ser resumidos na palavra ruptura: territorial, visual, ambiental, social. À abertura das grandes avenidas de vale em Salvador se seguiram valorizações e especializações de trechos da cidade: alterações nas centralidades e segregação de consumo de lugares a partir do acesso, ou não, aos meios de transporte motorizados. O aumento da velocidade dispersou a paisagem construída da cidade; afastou sua imagem física da sua imagem pública. Transformou muitas paisagens em "genéricas". As periferias das grandes cidades brasileiras se tornam assustadoramente parecidas, vistas através das lentes que as varrem por helicópteros nos programas policiais televisivos.

A velocidade midiática compõe e recompõe a cada momento a imagem da cidade. As várias Rio de Janeiro: de Ipanema; do Morro do Alemão e da Lapa. As diversas São Paulo: da Avenida Paulista; da COHAB e a do Pátio do Colégio. As muitas Salvador: do Porto da Barra; do Subúrbio Ferroviário; do Centro Histórico e da Avenida Paralela.

Do "controle" dessa imagem, no entanto, dependem economias como a do turismo e a dos seus mediadores publicitários. Bem como muitas das ações dos governos locais, em larga escala, comprometidos com as políticas de promoção da cidade para atração de capitais. Reforçar uma identidade municipal que possa ser comungada pelo maior número de pessoas passa a ser requisito básico da existência dos lugares em um mundo povoado por redes de cidades genéricas, cada dia mais parecidas, o que leva a questão urbana para o domínio das estratégias de marketing, sobretudo em domínios turísticos como Salvador. Última fronteira da identificação visual, as técnicas publicitárias tornam obscenas as particularidades de uma cidade e potencializam os fragmentos que se quer tomar pelo 
todo. O sucesso da empreitada é levar essa identificação ao ponto em que uma cidade possa virar uma marca, uma grife. Caso relativamente recente de Barcelona, a partir da década de 1990.

A relação entre as cidades e a produção das suas imagens baseadas nas paisagens move-se em consonância com o estatuto do próprio homem urbano contemporâneo (SIMMEL, 1973). Não é incomum que as paisagens mais recorrentes das cidades sejam antes os frutos de uma "distração" coletiva consensual, que consagra uma comunhão dos seus habitantes e visitantes com as imagens que lhe são confortáveis, do que processos baseados na legibilidade visual direta. O conforto vem justamente da possibilidade da redução das paisagens urbanas ao mínimo denominador comum e que implica na sua circulação em suportes diversos: desenhos, pinturas, fotografias, vídeos. E que, claro, ganha em intensidade com as cidades turísticas e os seus cartões postais, de caráter histórico ou não, como o caso de Salvador. Esse processo só é possível porque desejado, um pacto entre os que fazem e os que consomem as cidades. A publicidade funciona como mediadora dessa relação e as políticas de marketing, ligadas ao urbano, tentam estabelecer o que é conhecido nos estudos da comunicação como agenda-setting; um tipo de efeito social do campo midiático que seleciona os temas que o público discute num determinado momento. Quando essas políticas são bem-sucedidas as maiorias silenciosas movem-se ao seu encontro.

É por isso que as investigações que buscam mapear a legibilidade das grandes cidades do mundo capitalista contemporâneo, baseadas na recepção das suas paisagens, ainda que lancem mão de metodologias diversas, encontrarão resultados parecidos. Lá onde estão as paisagens mais bem cotadas na grande bolsa de imagens, hoje majoritariamente conduzida pelas mídias, estará a tradução hegemônica da cidade.

Muitos autores se dedicaram a estudar a cidade das paisagens mediadas, seja focando na sua visibilidade ou nas invisibilidades que provoca e que também lhes é inerente. Muitos outros ainda se dedicam. Em verdade, boa parte dos atuais estudos sobre a imagem da cidade ainda se situa, justamente, no ponto de observação em que enxerga as cidades contemporâneas como o reino das paisagens mediadas. Em última escala, a cidade se transforma no reino das aparências, onde "a realidade" estaria camuflada por estratégias do campo do poder: o capital transnacional, o Estado e a grande mídia.

Aqui nesse estudo, essa construção coletiva da imagem da cidade, a partir das diversas representações, é considerada, mas procura-se avançar para além das construções 
dos discursos: seja o turístico; seja o jornalístico, para se ancorar em fatores físicos mais perenes como os próprios elementos físicos (naturais e artificiais) da paisagem que podem ser captados com a visão.

Boa parte dos trabalhos sobre o tema se reportam aos estudos clássicos, notadamente aos livros A Imagem da Cidade (1960), de Kevin Lynch, e Paisagem Urbana (1971), de Gordon Cullen. Aqui se amplia esse conceito com as contribuições de François Ascher (1995) e também na atualização feita por Marcos Rodrigue (2009).

Um primeiro ponto que é consensual entre todos os autores é o de que a paisagem não é um conceito absoluto. É relativo. Sobretudo ao que comumente se entende, literalmente, por ponto de vista. O Elevador Lacerda, por exemplo, também em Salvador, que é um equipamento de grande escala e um dos principais cartões postais da cidade, não é uma "paisagem", como definição a priori. Ele é um edifício de importância histórica. Mas só se torna uma paisagem e um marco visual importante a partir da visão em certos pontos geográficos. Seguramente ele não é um marco visual visto da Rua Chile, na Cidade Alta. Mas a sua constituição como paisagem muda radicalmente com a sua visão a partir da Praça Cayru, na Cidade Baixa, onde ele se impõe em relação a todos os demais elementos do entorno, pela sua marcante verticalidade de $72 \mathrm{~m}$.

Outro condicionante que altera o conceito que se tem de paisagem é a velocidade de apreensão visual. Detalhes da pequena escala e texturas dos materiais que são possíveis de se visualizar numa caminhada pelas calçadas, na velocidade média de 5 a $6 \mathrm{~km} / \mathrm{h}$, podem passar completamente despercebidos num deslocamento de $60 \mathrm{~km} / \mathrm{h}$ numa via motorizada. $\mathrm{O}$ arquiteto baiano Fernando Peixoto, muito criticado em determinado momento pelo caráter gráfico das suas fachadas coloridas com materiais de baixo custo, como azulejos, costumava dizer que desenhava seus edifícios, construídos na Avenida Antônio Carlos Magalhães, para quem passava de carro. De fato, as escalas das chamadas avenidas de vale em Salvador, basicamente desenhadas para automóveis, privilegiam os deslocamentos e as vistas a partir de veículos motorizados.

Por fim, outra condicionante que determina o conceito de paisagem está na sua apreensão visual em tempo real ou não. Em geral, a vista em tempo real, seja numa apreensão in loco ou através de uma mediação técnica, como um drone ou transmissões ao vivo, ainda deixam a recepção dessa paisagem num campo mais aberto para interpretações. 
Já as imagens vistas a posteriori, em fotografias, pinturas, desenhos ou vídeos, estão muito mais condicionadas à seleção e à narrativa de quem faz o seu "recorte". É uma paisagem de "autor". É nesse tipo de paisagem, selecionada, que se monta os diversos discursos (FOUCAULT, 1971) que acabam por configurar mais facilmente uma imagem de cidade. A quantidade e/ou intensidade dessas visualizações são muitas vezes determinantes na construção da imagem de uma cidade, que é a percepção que cria o imaginário coletivo.

Tem-se, assim, que os diversos tipos de paisagem dependem principalmente de três condições: o posicionamento (placement), que implica numa posição do corpo de quem vê e isso implica no uso ou não de objetos técnicos; a velocidade de apreensão visual do corpo físico (o olho) ou do objeto técnico que o amplia e, por fim, a questão do tempo real dessa apreensão. Entende-se que a paisagem urbana atual é, na verdade, um complexo de paisagens que coexistem, estruturada por esses condicionantes, podendo-se qualificar melhor em que consiste essa rede para transformá-la num conceito que auxilie na leitura das paisagens urbanas contemporâneas.

A coexistência desses níveis também pressupõe uma relação dinâmica, de alternância e de intensidade, que constroem e reconstroem a paisagem urbana e a imagem da cidade continuamente, produzindo o visível e o invisível.

\section{O monotrilho e seu impacto na paisagem do subúrbio ferroviário}

O modal de transporte que vai ser implantado no subúrbio ferroviário de Salvador é do tipo monotrilho (monorail), onde as composições correm por um único trilho com características específicas para essa tecnologia. Como a maioria desses sistemas implantados pelo mundo, o monotrilho que está sendo apresentado pelo Governo do Estado da Bahia, ainda em modo de anteprojeto, vai se deslocar sobre uma estrutura de pilares e vigas de concreto em alturas variáveis. Os pilares distanciam-se uns dos outros em intervalos de cerca de $23 \mathrm{~m}$. As alturas dessa estrutura variam, segundo o anteprojeto, de $4 \mathrm{~m}$ a $14 \mathrm{~m}$ de altura, com média em torno de $8 \mathrm{~m}$ a $9 \mathrm{~m}$. O único trecho em que a estrutura se desloca em altura próxima do padrão atual dos trens é sobre a ponte São João, que liga São João do Cabrito ao bairro de Plataforma.

Além da estrutura de pilares e vigas que se repetem ao longo dos $13,5 \mathrm{~km}$, somase à essa infraestrutura, 15 estações padrão, também elevadas, chamadas de "parada típica" e a estação da Calçada, que tem características próprias. Trata-se, portanto, de um 
elemento novo na paisagem e que vai ter impactos variáveis dado a sua natureza de extensão linear. Para esse estudo a proposta é identificar e fazer essa análise por "regiões de identidade visual", seguindo a proposta de Kevin Lynch (1960) no que ele chama de "bairros".

Aqui o entendimento dessas regiões não se limita às definições legais dessas fronteiras, mas, sim, às características físicas que criam similaridades visuais ou "continuidades temáticas" que permitem a um observador se situar e saber que está em determinado lugar. São características físicas como os tipos de vias, os padrões construtivos dos imóveis, o tipo de ocupação dos lotes, a visibilidade ou não do mar, a presença ou não de marcos visuais, o papel da encosta na leitura dessas paisagens etc. Essas regiões são definidas, sobretudo, a partir da visibilidade pedestre para o monotrilho implantado. Isso implica na consideração de pontos de vistas e elementos visuais que sejam significativos para toda a região do Subúrbio Ferroviário e para a cidade de Salvador como um todo.

Outros elementos da "gramática visual" criada por Lynch (1960) dão suporte às "leituras" dessas regiões. Então são consideradas, também, as vias principais; os pontos nodais ou lugares de confluência de fluxos e os limites, que são elementos lineares que estabelecem espécies de fronteiras entre dois tipos de áreas e funcionam como referências laterais. E, por fim, os marcos visuais, que são elementos que podem se destacar de todo o seu entorno imediato por algum característica peculiar, como uma grande escala vertical ou horizontal ou mesmo uma forma inusitada que deixe claro a distinção entre "figura e plano de fundo", sendo esta a principal característica para sua definição segundo o autor.

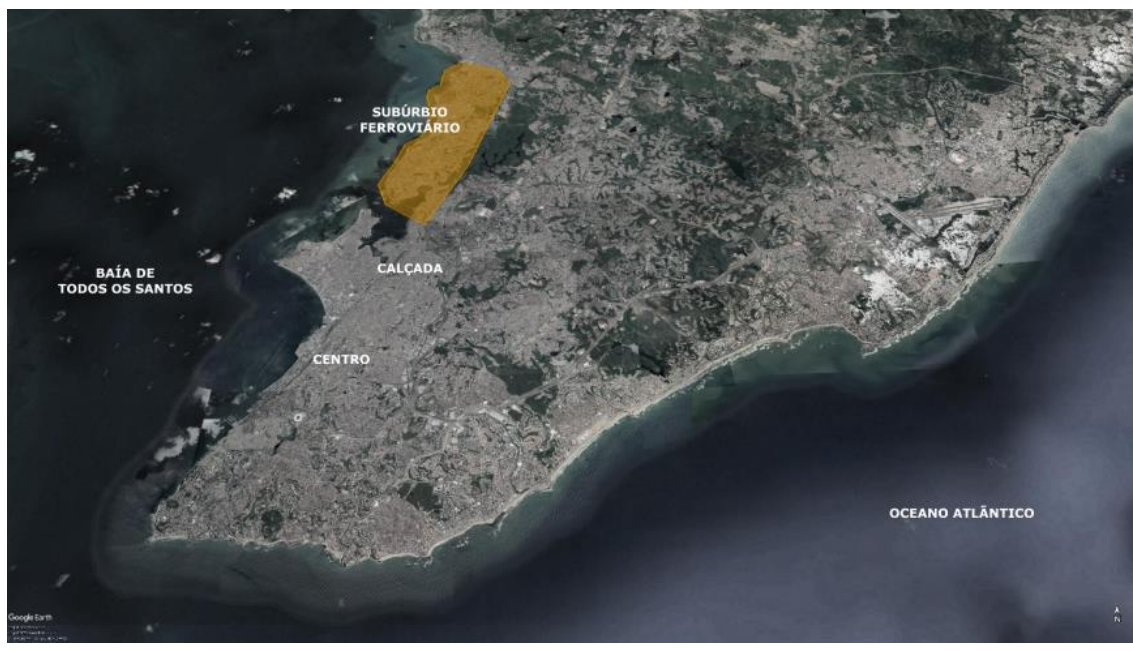

Fig.01 - Localização do Subúrbio Ferroviário em Salvador. M. Rodrigues, 2020, sobre base do Google. 
De uma forma geral, toda a região do Subúrbio Ferroviário (Fig.01) tem alguns elementos que a caracterizam como um "grande bairro", assim como também é possível assinalar peculiaridades ao longo de todo o percurso do monotrilho a ser implantado que permitem identificar regiões com características próprias.

Entre os elementos de continuidade temática, pode-se citar duas vias e dois limites. A primeira via é a que dá nome a toda região, a própria linha férrea, que vai ter seu percurso mantido na implantação do monotrilho. Essa via, que passa a ser elevada em quase toda sua totalidade, amplia sua visibilidade por essa característica, além de ser ela mesma um novo canal a criar novas perspectivas na paisagem. A outra via é a Avenida Afrânio Peixoto, que corta toda a extensão do Subúrbio, estabelecendo uma lógica de deslocamento por veículos automotivos, mantendo a mesma característica física em toda a sua extensão, que é a de um binário com duas faixas de rolamento em cada sentido, separadas por um canteiro onde hoje estão implantadas duas ciclovias.

Os dois limites, como as duas vias, também perpassam todo o trecho que vai da Calçada à Paripe, acentuando uma certa identidade visual de uma região que se estende linearmente. São eles a costa marítima, das baías de Itapajipe e de Todos os Santos e a falha geológica que gera encostas, hoje ocupadas, e que estabelece uma espécie de plano de fundo de toda essa paisagem.

Definidos os elementos que lhe dão afinidade visual, passa-se, então, à investigação que visa detectar suas distinções. Utilizando-se da metodologia de Gordon Cullen (1961), de registro sequencial, em combinação com os elementos visuais de Lynch (1977), foi possível mapear oito diferentes regiões ao longo do percurso do monotrilho, a partir de mudanças nos padrões das paisagens.

Tomando como ponto de partida a Estação da Calçada e seguindo no sentido norte, o primeiro trecho (Fig.02 e 03) está definido pela poligonal formada pelo Largo da Calçada, Rua Fernandes Vieira/Rua Luiz Maria e pela Rua Nilo Peçanha. O ponto de maior relevância é o próprio Largo da Calçada, onde está localizada a Estação da Calçada, datada de 1860. O anteprojeto e as imagens apresentadas mostram a estação do monotrilho na lateral da Estação histórica. A configuração espacial do Largo, em formato triangular, e a vista principal para a Estação a partir da Avenida Jequitaia, aparentemente, não são comprometidas. Também a arquitetura que se vê, na simulação em perspectiva, tem uma linguagem mais utilitária e minimalista que, em princípio, não afeta a leitura do 
edifício da antiga Estação. O outro marco visual importante a partir do Largo da Calçada é a Igreja dos Mares, que em nada é afetada pela nova estrutura.

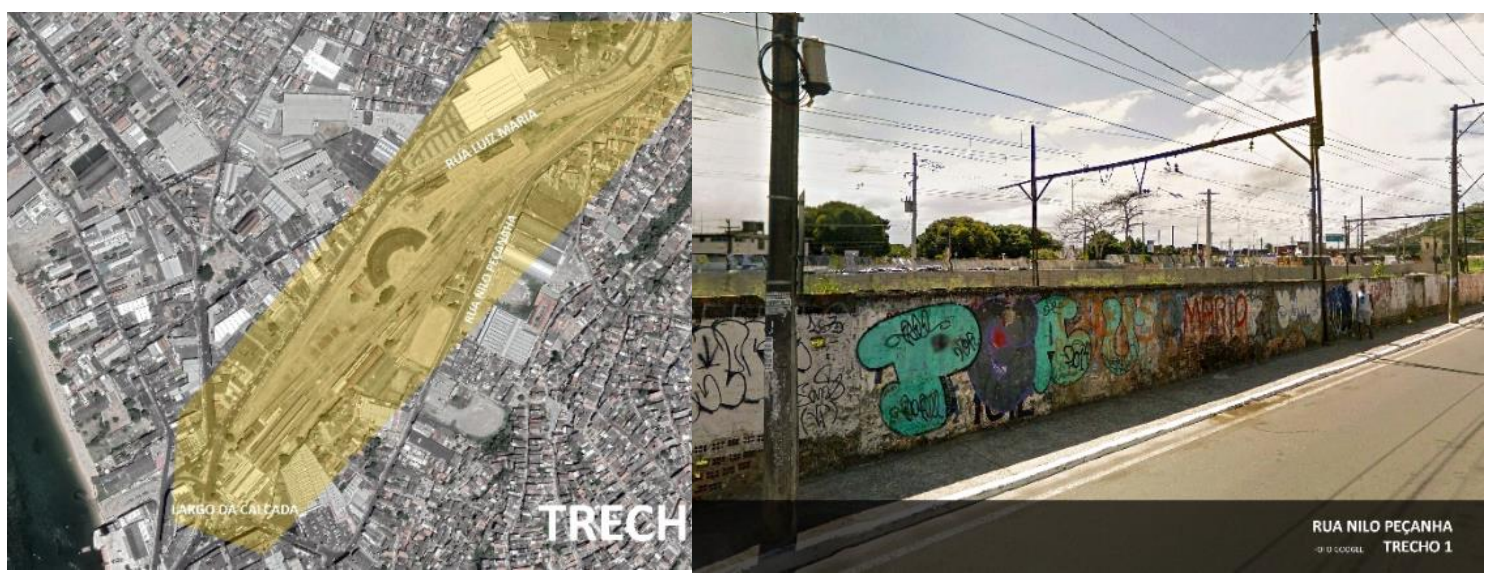

Fig.02 e 03 - Trecho 01, que parte da região da Estação da Calçada. Imagens Google, 2020.

O restante dessa região é marcado por um grande vazio do terreno da antiga rede ferroviária, com galpões e estruturas diversas em ruína. O entorno não apresenta nenhum elemento de importância paisagística que possa ser afetado negativamente pelo modal, nem individualmente nem em valor de conjunto. O plano de fundo é formado pela encosta do bairro da Liberdade, fortemente marcado por autoconstrução, constituindo uma paisagem genérica que se repete por toda cidade e, sobretudo, ao longo do Subúrbio Ferroviário.

O segundo trecho (Figs.04 e 05) começa com a Avenida Afrânio Peixoto, a partir do Viaduto dos Motoristas, e segue até o ponto em que a Avenida cruza com a Rua Voluntários da Pátria, no início do Lobato. Nesse trecho a estrutura do monotrilho praticamente não será percebida no conjunto da paisagem, correndo por trás da Avenida e camuflada pela alta densidade construída.

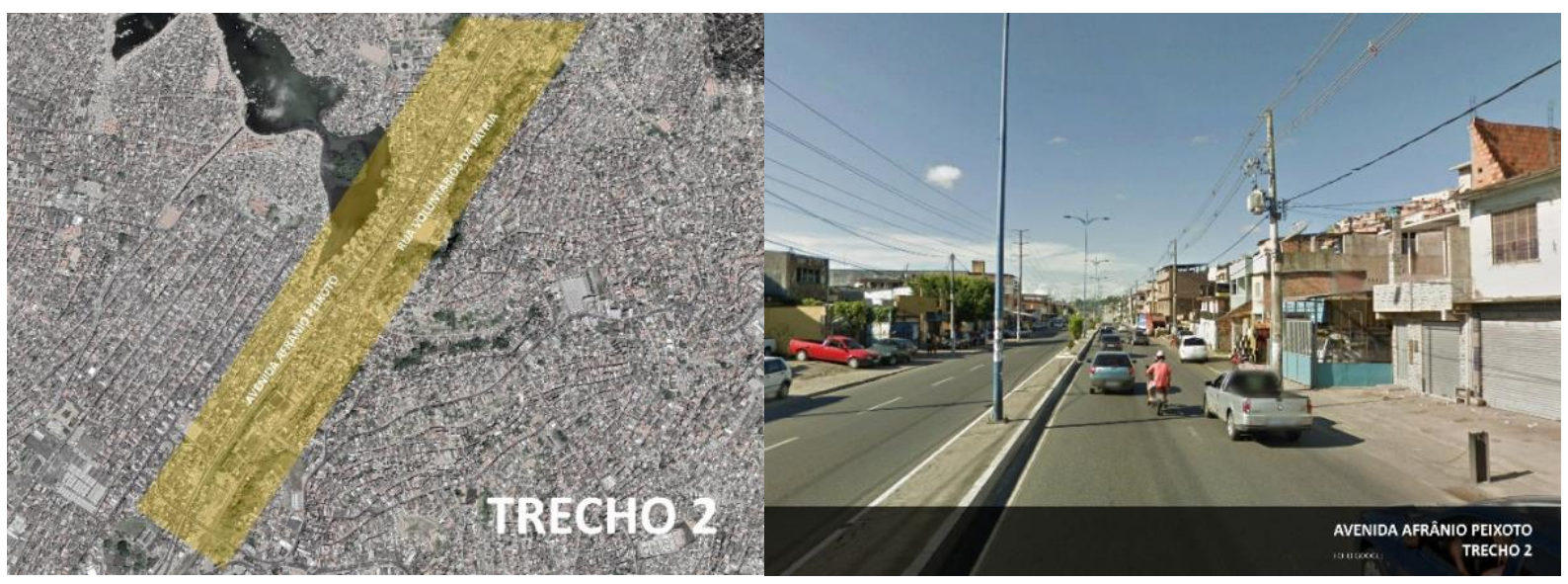

Fig.04 e 05 - Trecho 02, começo da Avenida Afrânio Peixoto. Imagens Google, 2020. 
O terceiro trecho (Figs.06 e 07) tem boa parte da sua identidade dada pela Baía de Itapajipe e fica delimitado, do lado direito, pelo início do Lobato, encerrando em São João do Cabrito na cabeceira da ponte São João e, do lado esquerdo, é definida pela Rua Porto dos Tainheiros, Largo da Ribeira e Rua da Penha. Nesse trecho a Avenida Afrânio Peixoto, principal via de todo o Subúrbio Ferroviário, mantém-se no sentido norte, enquanto o percurso do monotrilho, seguindo a linha férrea, bifurca em direção à costa da Baía de Todos os Santos. A via com maior importância nessa região e que serve de referência, como ponto de vista, para o monotrilho é a Rua Porto dos Tainheiros. Mas a visibilidade do monotrilho fica limitada pela distância de cerca de $1 \mathrm{~km}$ entre as duas costas, deixando a paisagem da região do Cabrito como a amálgama de um único plano, com a parte alta de Campinas de Pirajá. De novo, não há nesse trecho nenhum impacto paisagístico que comprometa a imaginabilidade da cidade.
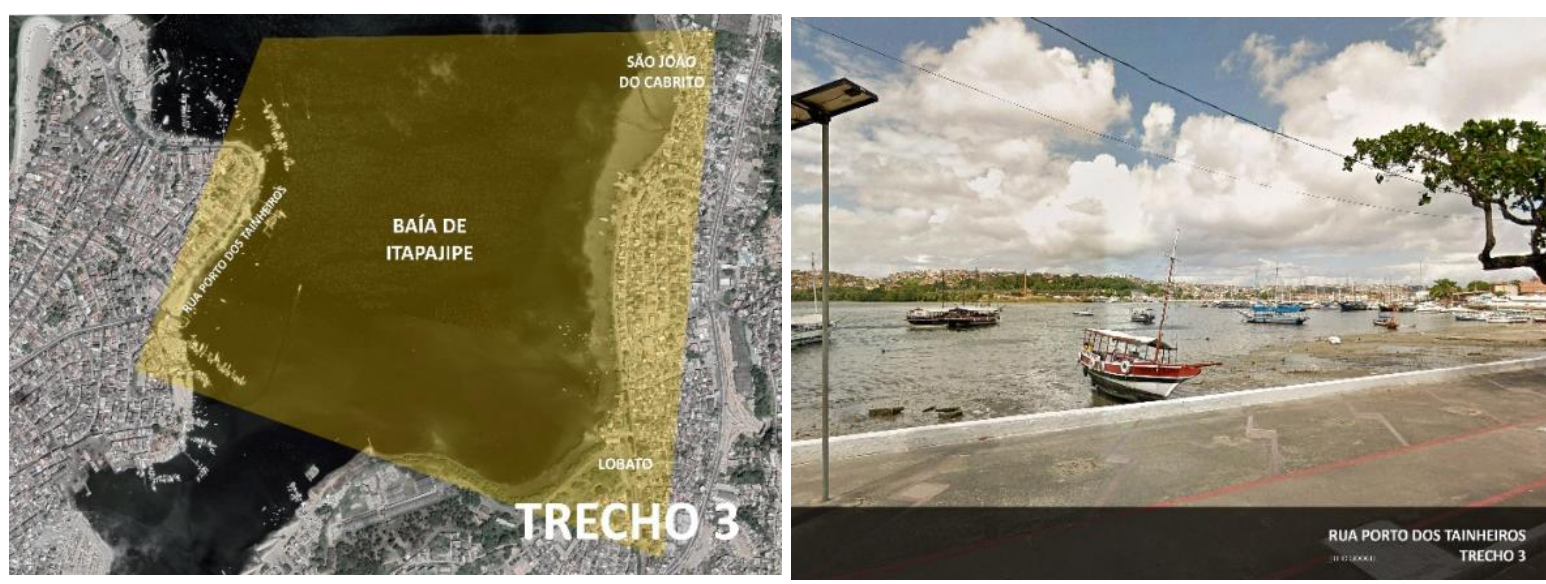

Fig.06 e 07 - Trecho 03, Baía de Itapajipe. Imagens de base Google, 2020.

O quarto trecho (Figs.08 e 09) é a própria ponte São João que corta a Baía de Itapajipe e liga São João do Cabrito ao bairro de Plataforma. A ponte, inaugurada em 1952 em substituição à antiga ponte de Itapajipe, é um dos elementos marcantes de todo o percurso e tem uma boa visibilidade a partir da Ribeira. Na verdade, esse trecho se conecta do ponto de vista paisagístico com o trecho 5 mas está aqui em separado por ser o único trecho onde o monotrilho passa em cotas mais próximas do nível do solo, aproveitando a própria estrutura da ponte existente para adaptar seu sistema. 

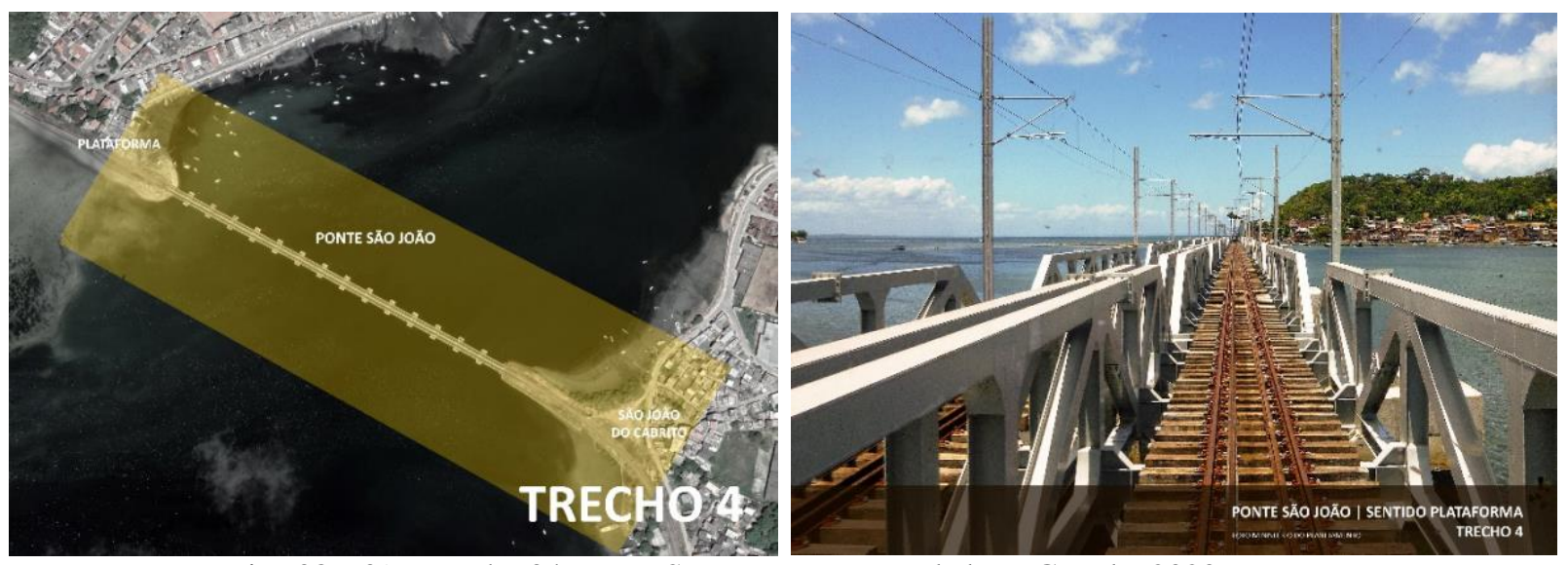

Figs.08 e 09 - Trecho 04, Ponte São João. Imagens de base Google, 2020.

O quinto trecho (Figs. 10, 11, 12 e 13) é a "boca" de saída da Baía de Itapajipe para a Baía de Todos os Santos, que abarca parte da costa marítima do bairro de Plataforma voltada para a Ribeira, indo do final da ponte São João até o final das ruínas da Fábrica São Braz, pela Rua Almeida Brandão e, no lado da Ribeira, a Rua da Penha, o Largo da Ribeira, a Rua dos Tamarindeiros da Penha e o início da Avenida Beira Mar. É desse trecho que sai a travessia marítima da Ribeira para Plataforma, sendo a menor distância entre as duas costas, bem como o ponto de melhor observação para as ruínas da Fábrica São Braz, que podem ser vistas até mesmo da praia da Penha.

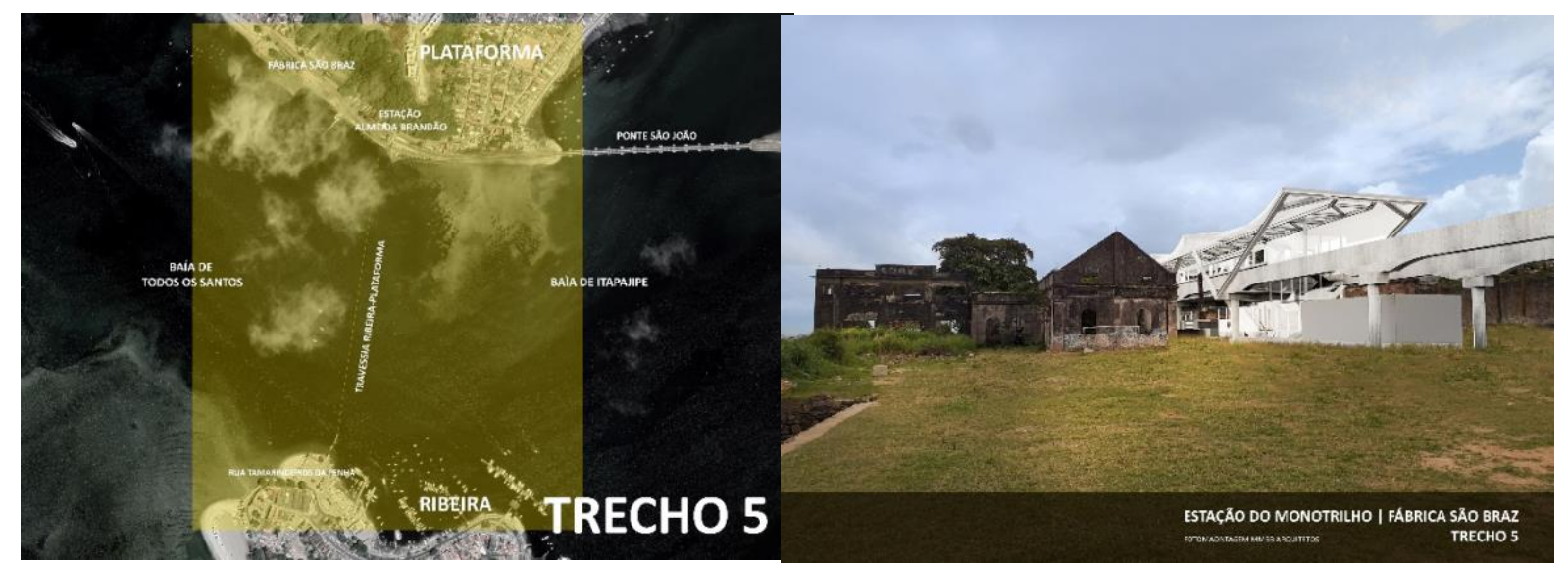

Fig.10 e 11 - Trecho 05, Saída da Baía de Itapajipe e ruínas da Fábrica São Bráz. Imagens MMBB Arquitetos e Google, 2020. 

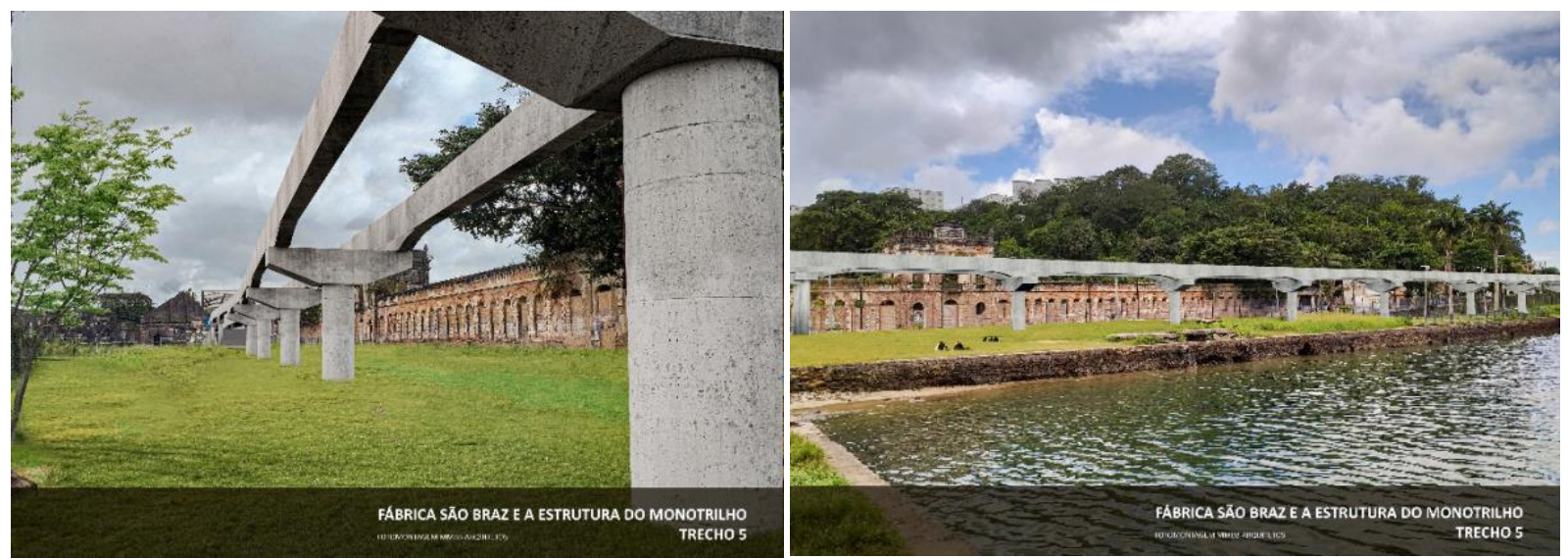

Figs.12 e 13 - Trecho 05, simulação da intervenção na Fábrica São Bráz. Imagens MMBB Arquitetos e Google, 2020.

Esse é um trecho particularmente importante, tanto do ponto de vista paisagístico quanto do ponto de vista da imagem da cidade, porque engloba áreas históricas e muito tradicionais, em Plataforma e na Ribeira, além de ter um bem cultural sob salvaguarda na esfera estadual, pelo Instituto do Patrimônio Artístico e Cultural da Bahia (IPAC), que são justamente as ruínas e o entorno da antiga Fábrica São Braz. A proteção legal (Decreto 8.357 de 05 de novembro de 2002), estabelece um raio de 200m de proteção em torno do sítio. O tombamento estadual chama a atenção para:

(...) o local onde existiu um engenho de açúcar, provavelmente o Engenho São João. Neste engenho, o Padre Antônio Vieira proferiu sermão dirigido à Irmandade dos Pretos de Nossa Senhora do Rosário. Além disso, o território onde se encontra a fábrica assistiu às invasões holandesas no século XVII, e às investidas dos portugueses nas batalhas pela independência da Bahia. A Fábrica São Braz pertenceu à CIA Progresso e União Fabril, de propriedade do senhor Bernardo Martins Catharino desde 1932 e tinha seu escritório localizado à Avenida Estados Unidos, no Edifício União. (BAHIA, 2002)

Ao que se acrescenta, ainda do ponto de vista histórico, a importância para a memória industrial da cidade e, sobretudo, para a própria constituição e identidade do bairro de Plataforma e, por consequência, do Subúrbio Ferroviário. Foi a partir da fábrica que se estabeleceu a Vila Operária e boa parte do povoamento da região, com gerações de famílias tendo parentes que trabalharam nas suas instalações.

Mas, além da importância histórica e como patrimônio tombado, protegido legalmente, é ainda importante chamar a atenção para o fato de que as ruínas da fábrica que tem a sua extensa estrutura de fachada ainda de pé, apesar do estado de arruinamento avançado - constituem um marco visual (LYNCH, 1977) de extrema relevância em todo esse trecho, servindo, não só como um "portal" de entrada para quem chega ao bairro de 
Plataforma pelo mar, mas também constituindo um monumento de referência paisagística para quem a vê do bairro da Ribeira (Fig.14) ou no mar (Fig.16), na transição entre a Baía de Itapajipe e a Baía de Todos os Santos.

A Fábrica São Braz tem ao seu favor, do ponto de vista da clareza da sua legibilidade visual e ao contrário dos outros trechos desse percurso, uma massa vegetal densa como seu "plano de fundo" que a destaca. Além da sua grande escala, já que a fachada da Fábrica tem uma extensão de cerca de $110 \mathrm{~m}$, o que caracteriza a clara distinção entre figura e plano de fundo, de que fala Lynch (1977).

Plataforma tem um lugar de destaque, dentre os diversos bairros que constituem o chamado Subúrbio Ferroviário, não apenas por ser a primeira dessas localidades cortadas pela linha férrea, mas por reunir boa parte da história da constituição desse subúrbio.

O local era uma fazenda do marinheiro português Antonio de Oliveira Carvalhal. A data de nascimento do bairro é de 16 de abril de 1638, dia em que o príncipe holandês, Maurício de Nassau, desembarcou na praia. Os portugueses bombardearam o bairro em 1823. Em 1851, o fazendeiro Almeida Brandão constrói uma usina que, 9 anos depois, seria transformada na Fábrica São Braz. (SALVADOR, 2020)

Outra fábrica que compõe a história de Plataforma é a União Fabril dos Fiais, mais conhecida como União Fabril que também contribuiu para o povoamento do local até meados do Século XX.

No processo de Independência da Bahia, em 1823, o local também foi usado pelos portugueses como via de comunicação entre o Norte, o Centro e a capital baiana, através da Estrada das Boiadas, atualmente chamada de Rua 8 de Novembro.

A linha férrea, no seu período áureo, era o principal agente estruturador do bairro de Plataforma, permitindo o abastecimento da feira local com mercadorias que vinham do interior, a chegada da iluminação elétrica, a presença do transporte público e a instalação da própria Fábrica de tecidos São Braz. Processos que deram lastro ao povoamento do bairro e a formação da Vila Operária.

O deslocamento da produção fabril para o sudeste, no final do século XIX, e a descoberta do petróleo, em meados do século XX, mudaram os rumos dos investimentos e do processo de produção no país, conduzindo ao fechamento da referida fábrica em 1959.

Isso, contudo, não diminui o seu importante papel na história do bairro e na vida dos seus moradores, pois o bairro cresceu a partir da fábrica, sendo difícil encontrar, nos 
dias atuais, alguém que não trabalhou ou tem pelo menos um parente que era empregado na indústria de tecidos. A Fábrica era, portanto, a alma do bairro (SERPA, 2001).

Complementa a importância paisagística desse entorno, também em Plataforma e próximas à Fábrica São Braz, a Estação Almeida Brandão, com suas antigas palmeiras imperiais (Fig.15) enfileradas que estão, definitivamente, no imaginário coletivo dos moradores dessa região e a própria ponte São João.

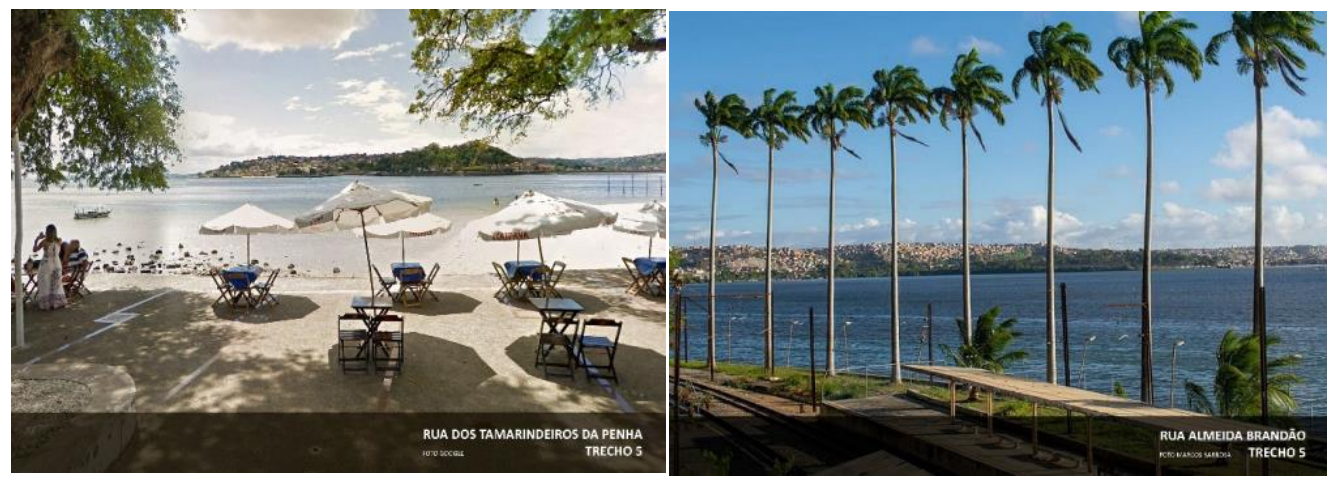

Figs.14 e 15 - Trecho 05, Vista a partir da Ribeira e Estação Almeida Brandão. Imagens Google e Marcos Barbosa, 2020.

Esses fatos históricos, ancorados num equipamento que significa a paisagem local, dão suporte à toda construção do imaginário sobre o local. Nesse caso, não só para os moradores do bairro, mas também para toda a cidade.

Nesse trecho a estrutura do monotrilho, segundo o anteprojeto apresentado e seguindo sempre o leito da linha férrea, passa em frente à fachada da Fábrica São Braz, o que compromete a clara visualização que se tem hoje da Fábrica, nas vistas a partir do mar e da Ribeira (Figs.14 e 15). Esse comprometimento não se dá pela diferença de
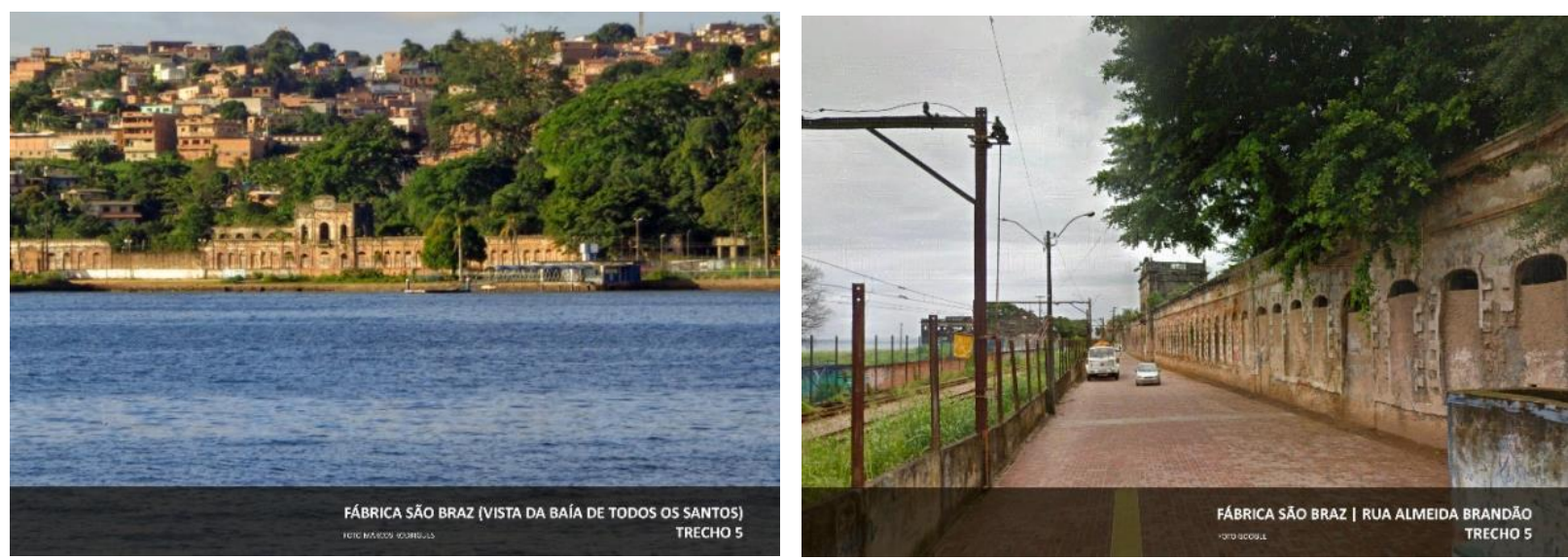

linguagem estética, que é inclusive interessante para se marcar períodos históricos específicos, mas, sim, pela constituição linear da estrutura de trilhos que corta toda a extensão da fachada. 
Figs.16 e 17 - Fábrica São Bráz vista e da Rua Almeida Brandão. Imagens Marcos Rodrigues, 2019 e Google, 2020.

Não havendo impedimentos técnicos, o ideal seria para que a subida da estrutura para as cotas aéreas, após a passagem pela Ponte São João, se desse após as ruínas da Fábrica e não logo após a Ponte.

O sexto e mais extenso trecho (Figs. 18 e 19), é todo o percurso da linha férrea a partir de Plataforma que segue até Periperi, no limite do Canal Paraguari, início do bairro de Coutos. Esse é o trecho onde a visão para a estrutura do monotrilho fica praticamente limitada às vistas a partir da Baía de Todos os Santos. Sem maiores prejuízos à paisagem, mesmo pelo mar, já que a estrutura aérea do monotrilho atravessa uma região caracterizada por uma paisagem genérica composta basicamente por autoconstruções precárias.
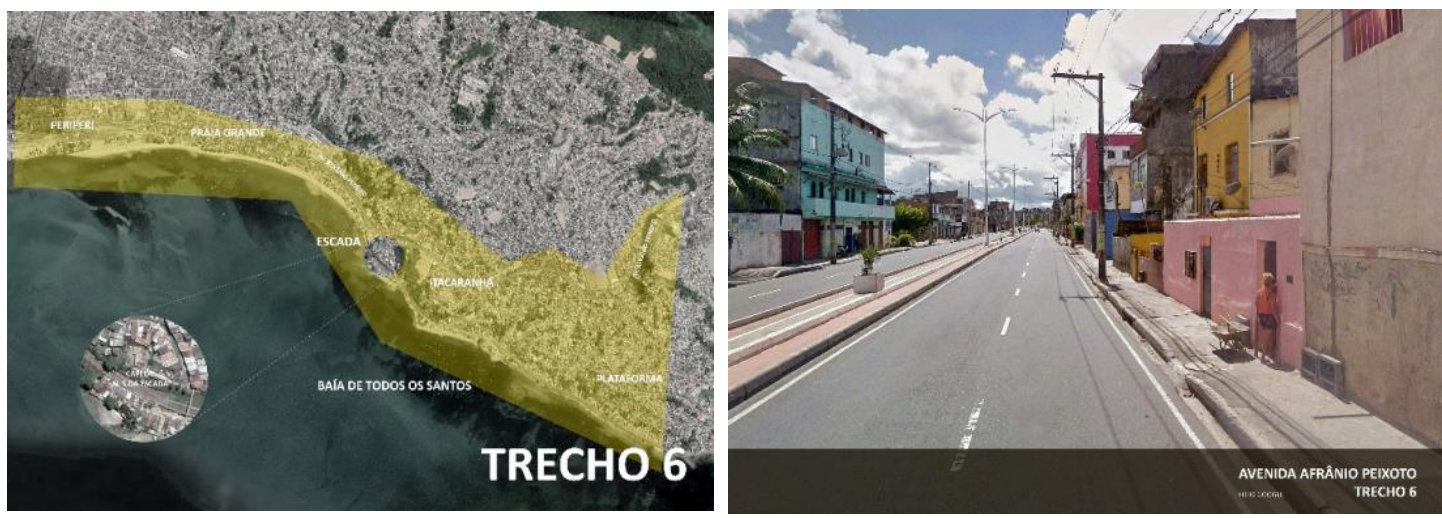

Figs.18 e 19 - Trecho 06, Avenida Afrânio Peixoto. Imagens de base Google, 2020.

A única exceção nesse trecho é a Capela de Nossa Senhora da Escada (Fig.20), construção do Século XVI que recebeu tombamento federal pelo antigo SPHAN, em 1962 e foi restaurada pelo mesmo órgão em 1966. No site do atual Instituto do Patrimônio Histórico e Artístico Nacional (IPHAN) tem-se a seguinte descrição:

A capela foi construída por Lázaro Arévolo, em terras de sua propriedade, sendo doada aos jesuítas em 1572. Implanta-se a capela sobre uma pequena colina voltada para o mar, à margem do acesso ferroviário da Av. Suburbana, ao norte da cidade. Construída em alvenaria de pedra e tijolo, a capela possui alpendre, nave, coro, capelamor, sacristia e sineira em arco localizada ao lado da epístola. Sua planta é uma transição das antigas capelas rurais - de espaço único - e aquelas de partido em "T", que justapõem sacristia e consistório à capela-mor. Apresenta nave única e capela-mor e sacristia num corpo que se distingue do restante da edificação. $\mathrm{O}$ alpendre ou copiar, 
elemento frequente nas construções rurais dos primeiros séculos de colonização, foi substituído por um com tacaniça em lugar daquele em duas águas - então existente -, quando o SPHAN restaura o prédio em 1966. É também desta época a fachada atual, que procura reestabelecer a concepção original do edifício. O púlpito com bacia monolítica e sineira, tem acesso por escadarias externas. O altar-mor é do séc. XIX, pisos e forros do século XX. No seu interior, encontra-se uma imagem de Nossa Senhora, do séc. XVIII. (BRASIL, 1962)
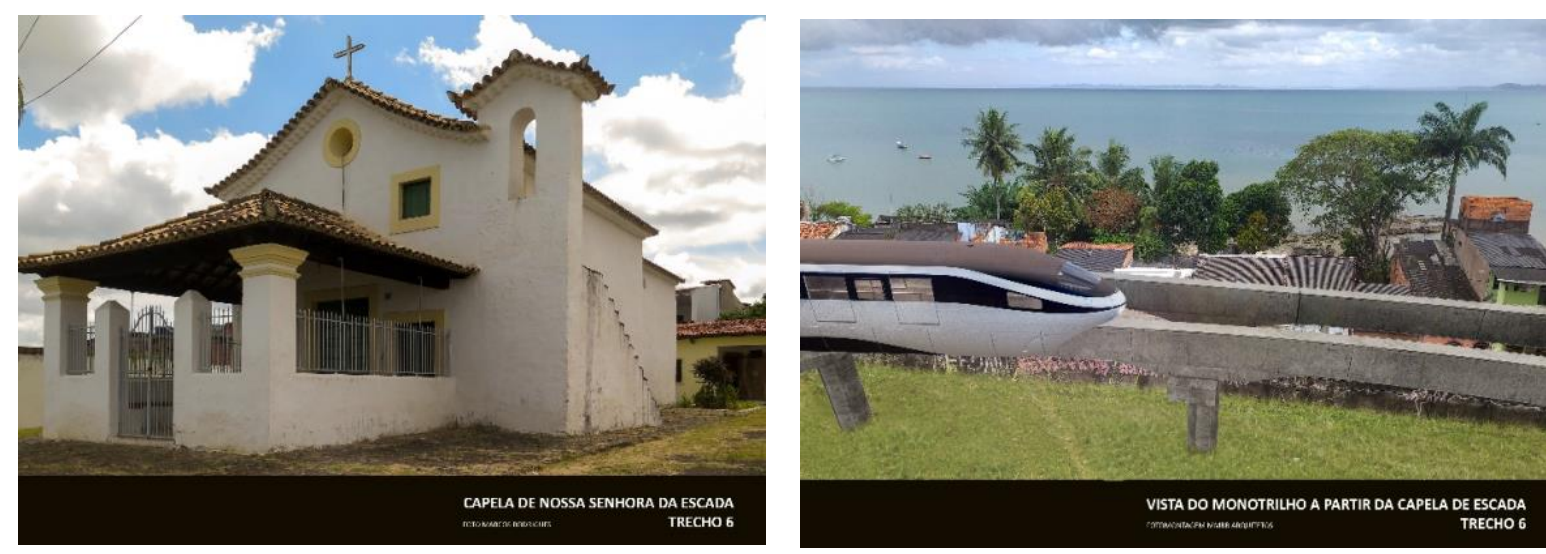

Fig. 20 e 21 - Igreja Nossa Senhor da Escada

Imagens Marcos Rodrigues, 2019, MMBB Arquitetos e Google, 2020.

Na relação com a estrutura a ser implantada pelo monotrilho, a restrição legal vem do Decreto-Lei N.25 de 30 de novembro de 1937 e que no seu Art. 18 que diz "Sem prévia autorização do Serviço do Patrimônio Histórico e Artístico Nacional, não se poderá, na vizinhança da coisa tombada, fazer construção que lhe impeça ou reduza a visibilidade."

Pelas fotomontagens e anteprojeto fornecidos para a realização desse estudo (Fig.21), a estrutura do monotrilho passa em cota de implantação abaixo da linha que possa comprometer a visibilidade da capela. Da mesma forma não parece haver prejuízo da vista da capela para a Baía, considerando a peculiaridade da construção, com a sua fachada principal voltada para o mar. Essas são as duas condições que, em sendo observadas, não criam conflitos com a visibilidade do bem tombado.

O sétimo trecho (Figs. 22 e 23) é a orla do bairro de Coutos até Paripe. A peculiaridade desse trecho é ter boa parte da sua extensão, onde a Avenida Afrânio Peixoto fica contígua à linha férrea, com toda a visão para a Baía de Todos os Santos. As duas vias seguem lado a lado, com a Estação da linha férrea de Coutos se abrindo diretamente para a avenida. 

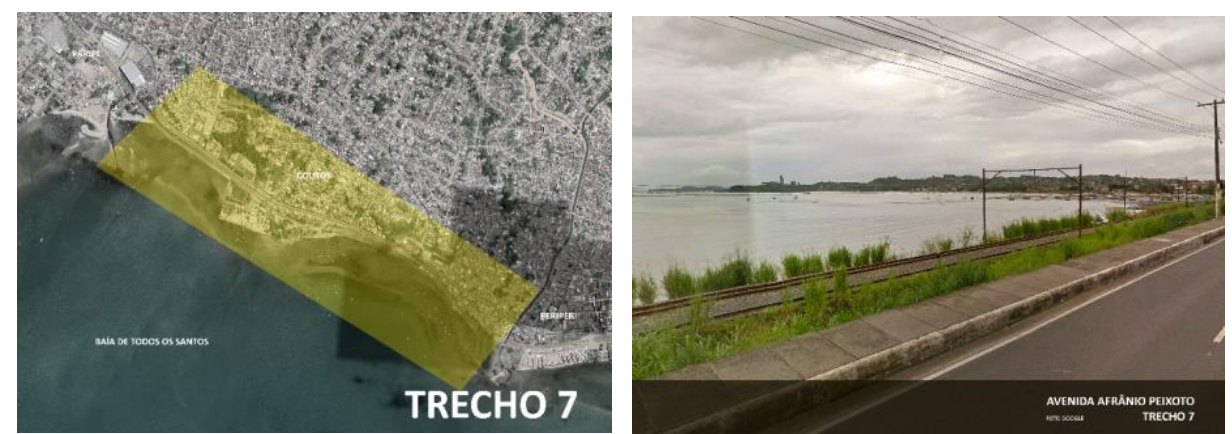

Figs.22 e 23 - Trecho 07, com detalhe da Avenida Afrânio Peixoto e treco da Baía. Imagens Google, 2020.

A implantação da linha aérea do monotrilho vai definitivamente modificar a paisagem desse trecho, introduzindo um marco visual na região, inclusive com as duas estações propostas. Será uma referência, visto tanto do bairro de Coutos quanto do mar, já que "perde" o plano de fundo formado por construções das outras regiões. Elimina, no entanto, um limite, que é a própria linha férrea, permitindo um acesso ao mar.

O oitavo e último trecho (Figs. 24 e 25) é a chegada do percurso no bairro de Paripe. Nesse ponto a Avenida Afrânio Peixoto volta a se bifurcar em relação à linha férrea e o curto percurso do monotrilho avança para dentro do bairro de Paripe numa área de uso misto, onde construções no padrão similar ao de todo o Subúrbio Ferroviário térreas ou em dois pavimentos - coexistem com grandes galpões de mercados, comércio de atacado e ambulantes.

A configuração espacial também tem no seu entorno loteamentos com quadras e vias planejadas. Não há nenhum elemento paisagístico que qualifique a legibilidade da área, sendo mais uma região com uma paisagem genérica, onde a introdução da estrutura do monotrilho pode vir a se tornar um marco visual.
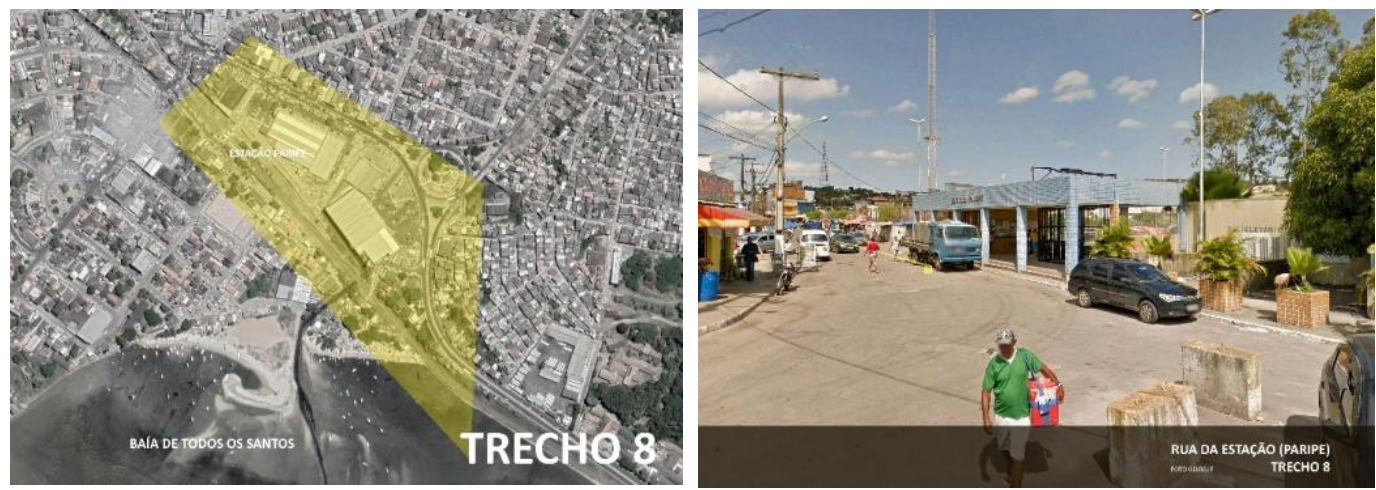

Figs.24 e 25 - Trecho 08 e foto da Estação Paripe. Imagens Google, 2020. 


\section{Conclusões}

O Subúrbio Ferroviário de Salvador é uma região da cidade com características visuais próprias e que a diferencia do resto da cidade. A sua configuração de faixa linear estendida é reforçada pelas linhas da costa marítima, da rede férrea, da Avenida Afrânio Peixoto e da falha geológica que define as encostas. Essa configuração de uma identidade visual, à exceção das perspectivas a partir do mar, não significa, porém, que exista uma qualidade paisagística no conjunto. Ao contrário, a maior parte da região se repete numa sucessão monótona de autoconstruções genéricas que poderiam estar em qualquer periferia do país. Infelizmente, boa parte do potencial paisagístico da região foi exaurido pelo adensamento construtivo sem critérios.

Saindo da lógica dos panoramas tomados em deslocamento e, considerando alguns pontos específicos, no entanto, essa região da cidade tem algumas das mais belas vistas para a Baía de Todos os Santos e, até mesmo para a própria cidade de Salvador.

Também há que ser considerada a importância histórica da linha férrea e dos antigos equipamentos industriais na configuração dessa região e da própria cidade de Salvador. O bairro de Plataforma, por exemplo, merece maior cuidado nesse sentido. Pela história que carrega e pela importância na estruturação paisagística de uma das partes mais expressivas da Cidade Baixa, da Baía de Todos os Santos e do próprio Subúrbio.

A implantação da estrutura (vias e estações) para o funcionamento do monotrilho não compromete a paisagem na maior parte do seu percurso, nesse trecho da Calçada a Paripe. A linha vai cortar o Subúrbio até com certa invisibilidade por conta da estruturação das construções nas encostas.

Para uma escala de proximidade, dos moradores da região, a estrutura acrescenta novos marcos visuais e a estrutura aérea pode permitir trechos de acesso ao mar e até mesmo a implantação de parques lineares.

Também o monotrilho faz surgir, a partir do seu deslocamento elevado, novas paisagens da Baía, da cidade e do próprio Subúrbio, o que pode ser, além de um ganho imediato para os seus moradores, um atrativo até de cunho turístico.

Os pontos de maior conflito identificados aqui nesse estudo são as áreas da Fábrica São Braz, no bairro de Plataforma, e a Capela de Nossa Senhora da Escada. O anteprojeto apresentado, no entanto, já deveria ter sido baseado num edital que contemplasse a parte de Patrimônio, evitando conflitos posteriores entre as diversas instituições envolvidas na sua salvaguarda. A inexistência de um estudo prévio, como este produzido aqui, 
infelizmente ainda mostra certa negligência com as questões da paisagem urbana, mesmo aquelas que estão sobre proteção de leis específicas.

\section{Referências bibliográficas}

ASCHER, François. Metapolis (ou l'avenir des villes). Paris: Éditions de l'Aube, 1995. BAHIA. Decreto No 8.357/02, de 05/11/2002. Salvador: IPAC, 2002.

BRASIL. Capela de Nossa Senhora da Escada. In Livro do Tombo Histórico: Inscrição n 340, de 11/04/1962. Brasília: IPHAN, 1962.

BRASIL. Estatuto da Cidade. Brasília: Senado Federal, Subsecretaria de Edições Técnicas, 2008.

CULLEN, Gordon. Townscape. Londres: The Architectural Press, 1961.

FOUCAULT, Michel. L'ordre du discours: Leçon prononcée au Collège de France le 2 décembre 1970. Paris: Éditions Gallimard, 1971

KOOLHAAS, Rem. The Generic City in Rem Koolhaas \& Bruce Mau, S,M,L,XL. New York: The Monacelli Press, 1995.

LYNCH, Kevin. A imagem da cidade. São Paulo: Martins Fontes, 1977.

RODRIGUES, Marcos A. Nunes. Dromorfoses da Cidade: A paisagem urbana na era da sua circulação numérica. Tese de Doutorado. Salvador: UFBA, 2009.

RODRIGUES, Marcos A. Nunes. Imago Urbis. Escritos sobre Paisagem Urbana e Imagem da Cidade. Salvador: Gattopardo, 2011.

SALVADOR. Cultura Todo Dia: $O$ bairro de Plataforma. In www.culturatododia.salvador.ba.gov.br . Salvador: Fundação Gregório de Mattos, 2019. Último acesso em 22 de junho de 2020.

SIMMEL, Georg. "A metrópole e a vida mental”. In: VELHO, Otávio Guilherme (org.). O fenômeno urbano. Rio de Janeiro: Zahar Editores, 1973.

SERPA, Angelo (org.). Fala periferia! Uma reflexão sobre a produção do espaço periférico metropolitano. Salvador: UFBA, 2001

VIRILIO, Paul. O espaço crítico e as perspectivas do tempo real. Rio de Janeiro: Editora 34, 1993.

VASCONCELOS, Pedro de Almeida. Salvador: transformações e permanências (15491999). Salvador: Edufba, 2016.

Data de Recebimento: 06/07/2020

Data de Aprovação: 29/10/2020 


\section{Para citar essa obra:}

RODRIGUES, Marcus Antonio Nunes. MELLO, Márcia Maria Couto A utilização de registros sequenciais na avaliação do impacto na paisagem urbana do subúrbio ferroviário de salvador In: RUA [online]. Volume 26, número 2 - p. 361-385 - e-ISSN 2179-9911 - Novembro/2020. Consultada no Portal Labeurb - Revista do Laboratório de Estudos Urbanos do Núcleo de Desenvolvimento da Criatividade.

http://www.labeurb.unicamp.br/rua/

Capa: Fig.01 - Localização do Subúrbio Ferroviário em Salvador. M. Rodrigues, 2020, sobre base do Google.

Laboratório de Estudos Urbanos - LABEURB

Núcleo de Desenvolvimento da Criatividade - NUDECRI

Universidade Estadual de Campinas - UNICAMP

http://www.labeurb.unicamp.br/

Endereço:

LABEURB - LABORATÓRIO DE ESTUDOS URBANOS

UNICAMP/COCEN / NUDECRI

CAIXA POSTAL 6166

Campinas/SP - Brasil

CEP 13083-892

Fone/ Fax: (19) 3521-7900

Contato: http://www.labeurb.unicamp.br/contato 